Download

UDC 911.3 https://doi.org/10.17721/2308-135X.2021.62.12-17

Mashika Hanna Vasylivna, Doctor of Geographical Sciences, Associate Professor Uzhhorod National University, Uzhhorod, Ukraine,

e-mail: mashika.g.v.@i.ua

Nych Tetyana Vasylivna, Candidate of Geographical Sciences Taras Shevchenko National University of Kyiv, Kyiv, Ukraine, e-mail: tatyana2510@ukr.net

\title{
GEOPOSPATIAL ORGANIZATION OF TOURIST AREAS IN THE CONTEXT OF RECREATIONAL NATURE MANAGEMENT
}

The purpose of this article is a theoretical justification and practical study of the geospatial organization of tourist areas in the context of recreational nature.

Method. General scientific methods were used in the research, in particular analysis and synthesis, methods of comparison and generalization, system approach, induction and deduction and specifically scientific methods: historical-geographical, comparative-geographical. As a methodological basis used developments, which are set out in the scientific works of Yu.A. Vedenina, O.O Beydika, O.O. Lyubitseva, M.Y. Rutinsky., V.I. Stafiychuk, V.L Petranovsky, L.I. Topalova and others. Nature management is considered as an applied scientific field based on natural science knowledge and a set of fundamental socio-economic disciplines. 
Research results. Theoretical and methodological provisions of research of geospatial organization of tourist territories taking into account recreational nature use (in this case it is considered as practice and social experience of use of natural conditions of natural and recreational resources) in the context of balanced development are developed.

Scientific novelty. A comprehensive approach to the optimization of tourist areas in terms of recreational and tourist activities, taking into account the needs of recreational nature, the balance of interests of society and nature. Research and evaluation of the mechanism of formation of geospatial organization of tourist areas, taking into account the use of emerald objects.

Practical significance. It consists in the development and practical application of the theoretical basis for the study of tourist areas in the context of recreational nature. The results of research can be implemented during the development of measures to adapt areas to recreational loads, changes in environmental conditions and the reverse impact of recreational and tourist activities, in teaching disciplines "Theory and practice of recreational and tourist nature", "Nature", "Rural green tourism". "Fundamentals of green tourism and recreation", forming the consciousness of the younger generation during training in the Free Economic Zone.

Key words: tourist territory, geospatial organization, recreational food use.

References

1. Bejdy'k O.O., Novosad N.O. Unikal'na Ukrayina : geografiya ta resursy' tury'zmu : navch. posib. - K. : Al'terpres, 2013.

2. Dudny'k I. M.Osobly'vosti geoprostorovoyi organizaciyi poslug rozdribnoyi torgivli v sil's'kij miscevosti [Elektronny'j resurs]. Rezhy'm dostupu:

https://periodicals.karazin.ua/geoeco/article/view/9517

3. Lyubiceva O.O., Mal's'ka M.P., Zin'ko Yu.V. Konceptual'ni zasady' geografiyi rekreaciyi i tury'zmu [Elektronny'j resurs]. Rezhy'm dostupu: 
http://www.geolgt.com.ua/images/stories/zbirnik/vipusk11/v111.pdf

4. Lyubiceva O.O. Ry'nok tury'sty'chny'x poslug. Navchal'ny'j posibny'k. 2-e vy'd.,pererob ta dop.-K.:»Al'terpres»,2003.-436s.

5. Lyubiceva O.O., Kochetkova I.V. Teorety'chni ta pry'kladni py'tannya rekreacijno-tury'sty'chnogo pry'rodokory'stuvannya v stoly'chnomu misti [Elektronny'j resurs]. Rezhy'm dostupu: https://tourlib.net/statti_ukr/lubiceva4.htm

6. Mal's'ka M. P., Antonyuk N. V., Gany'ch N. P. Mizhnarodny'j tury'zm ta poslugy': Pidruchny'k. - K.: Znannya, 2008. - $661 \mathrm{~s}$.

7. Mal's'ka M. P. Formuvannya i rozvy'tok prostorovy'x sy'stem poslug (teoriya ta prakty'ka realizaciyi): avtoref. dy's. ... d-ra ekon. nauk : 08.00 .05 [Elektronny'j resurs] /; NAN Ukrayiny', In-t region. doslidzh. — L., 2011. — 40 s.: ry's. — ukp. [Elektronny'j resurs]. Rezhy'm dostupu: http://www.lgtinfo.com.ua/images/stories/disertation/mal1.pdf

8. Pushkar B.T., Pushkar Z.M. Tery'torial'na organizaciya rekreacijnogo gospodarstva regionu. - Ternopil': «Vektor» 2014. - 196s. [Elektronny'j resurs]. Rezhy'm dostupu: http://dspace.wunu.edu.ua/bitstream/316497/2589/1/tery'torial'na organizaciya=verstka.pdf.

9. Radchenko E. Ye. Teorety'chni osnovy' formuvannya ta rozvy'tku tury'sty'chnogo potencialu regionu [Elektronny'j resurs]. Rezhy'm dostupu:

http://www.economy.nayka.com.ua/pdf/12_2018/214.pdf.

10. Regional'na dopovid' pro stan navkoly'shn'ogo pry'rodnogo seredovy'shha v Ivano-Frankivs'kij oblasti v 2018 roci[Elektronny'j resurs]. Rezhy'm dostupu:

http://www.if.gov.ua/files/uploads/\%D0\%A0\%D0\%95\%D0\%93\%D0\%86\%D0\%9E\%D0\%9D\%D0 \%90\%D0\%9B\%D0\%AC\%D0\%9D\%D0\%90_\%D0\%94\%D0\%9E\%D0\%9F\%D0\%9E\%D0\%92\% D0\%86\%D0\%94\%D0\%AC_2018.pdf. 
11. Regional'na dopovid' pro stan navkoly'shn'ogo pry'rodnogo seredovy'shha u L'vivs'kij oblasti v 2019 roci» [Elektronny'j resurs]. Rezhy'm dostupu:

https://drive.google.com/file/d/1DK8sRIPP08u3P6b3h_N879NaFEae5EcT/view .

12. Regional'ni dopovidi pro stan navkoly'shn'ogo pry'rodnogo seredovy'shha u 2019 roci Chernivecz'ka oblast'[Elektronny'j resurs]. Rezhy'm dostupu:

https://mepr.gov.ua/news/35990.html.

13. Petranivs'ky'j V.L., Ruty'ns'ky'j M.J. Tury'sty'chne krayeznavstvo. Navch. posibny'k. - L'viv: Znannya, 2006. - $168 \mathrm{~s}$.

14. Stafijchuk V. I. Rekrealogiya: navchal'ny'j posibny'k. - Xerson: OLDI PLYuS, 2017. - 428 s.

15. Telyura N.A. Teorety'chni aspekty' rekreacijnogo pry'rodokory'stuvannya [Elektronny'j resurs]. Rezhy'm dostupu:

http://dspace.nbuv.gov.ua/bitstream/handle/123456789/34934/19-Teljyra.pdf?sequence=1 .

16. Shhorichni nacional'ni dopovidi pro stan dovkillya Zakarpattya ta ekologichni pasporty' Zakarpats'koyi oblasti [Elektronny'j resurs]. Rezhy'm dostupu: https://ecozakarpat.gov.ua/?page_id=308.

17. Beydik A., Topalova O. (2018) Theoretical and practical aspects of recreation and tourism environmental management. Visnyk Kyivskogo nacionalnogo universytetu imeni Tarasa Shevchenka GEOGRAFIYa [Bulletin of Taras Shevchenko National University of Kyiv, Geography], 1 (70), 15-21 (in Ukrainian, abstr. in English). [Elektronny'j resurs]. Rezhy'm dostupu: https://visnyk-geo.knu.ua/wp-content/uploads/2018/09/70-3.pdf. 